\title{
Translation of Smile and Metaphor from the Cultural Perspective
}

\author{
Yanping $\mathrm{Hu}^{\mathrm{a}}$, Yongheng Wang ${ }^{\mathrm{b}}$ \\ School of Foreign Languages, Southwest University for Nationalities, Chengdu 610041, China. \\ aleochengdu@163.com, b1532698155@qq.com
}

\begin{abstract}
As important figures of speech, simile and metaphor are marked with unique national and cultural colors. Therefore, the sense of simile and metaphor is frequently culture-specific. Approaches to cultures involved in the translation can be generally divided into foreignization (SL culture-orientation) and domestication (TL culture-orientation). In order to reproduce cultural connotations and pragmatic meanings of simile and metaphor, translators often use these techniques: literal translation, literal translation plus explanation, literal translation plus annotation, substitution and free translation.
\end{abstract}

Keywords: Simile; metaphor; translation; foreignization; domestication; techniques.

\section{Introduction}

Simile and metaphor are widely employed in English and Chinese. Both aim to make our speech and writing vivid, and thus enhance the expressiveness of our language. Due to different life experiences, customs, religions, geography and histories as well as aesthetic tastes, different vehicles are used in English and Chinese, which reflects their different cultural values. Therefore, the sense of simile and metaphor is frequently culture-specific (Snell-Hornby, 2001, p.56).

As cross-cultural communication, translation is not only the transfer between languages but also the transfer between cultures. In the past 30 years, a "culture turn" has been working in translation circles. Especially in the translation of simile and metaphor, cultural elements are of crucial importance.

\section{Cultural Elements in Simile \& Metaphor and Their translation}

\subsection{Cultural Connotations in Simile and Metaphor.}

Logan Pearsall Smith has ever said, "Most of our figurative expressions (esp. simile and metaphor) are created by common people, resulting from the careful observation on their jobs and hobbies". (Logan Smith, 1943, p.10) Blacksmith will say "strike while the iron is hot"; teachers could teach students "more haste, less speed"; fishermen know how "to pass fish eyes for pearl" while sailors feel frightened with something "over head and ears". Since figurative language is mostly from common people, it can exactly and truly reflect features of the history in a race, its economy, geography, customs and psychology etc. In this way, figurative language is like a mirror for us to discover what parts of two cultures overlap and what parts differ. Cultural elements greatly determine one's choice and understanding of certain vehicles.

\subsection{Translation as a Cross-cultural Event.}

It is universally acknowledged that translation is not only the product of cultural exchange but also the most efficient and important way for cultural exchange. With the study of translation going forward, linguists and translators put forward openly that translation is not merely a linguistic activity but also a cross-cultural event. Peter Newmark has ever pointed out that translation is the most economical method of explaining one's culture's way to another and translation mediates cultures (Katan, 1992, p.2). Vermeer has for many years vehemently opposed the view that translation is simply a matter of language. Lame Hewson and Jacky Martin also state that translation is the exploration of an unbridgeable gap and of a tension between cultures, and its function is to develop cross-cultural constructions while at the same time bridging and underlining the differences (Hewson \& Martin, 1993, p.25). Susan Bassnett believes that translation must take place within a framework of culture (Bassnett, 1991, p.13). Translation, as cross-cultural communication, must be made both on linguistic basis and on a cultural one, because language and culture are so interdependent that one 
implies the other. As a significant medium for cultural exchange, translation aims to promote understanding among different countries and nations, hence to improve communication across cultures.

\section{Translation of Simile and Metaphor from the Cultural Perspective}

\subsection{Two Orientations in Translation.}

Since English and Chinese belong to two fundamentally different cultures, the translator has to fulfill his task of translation over the striking gaps between the SL culture and the TL culture. Usually, he has to make a choice between a domestication method---a reduction of the foreign text to the TL cultural system, making the foreign text recognizable and familiar, and a foreignizing method---a representation of the particular cultural genius of the foreign text, making the reader see the cultural and linguistic differences.

The dichotomy of domestication and foreignization can be traced back to almost 200 year ago. In a lecture On the Different Methods of Translation, Friedrich Schleiermacher, a German theologian and philosopher said, "There are only two methods of translating, either the translator leaves the author in peace, as much as possible, and moves the reader towards him; or he leaves the reader in peace, as much as possible, and moves the author towards him" (Venuti, 1995, p.19). From the lecture, Venuti develops the definition of domesticating method, an ethnocentric reduction of the foreign text to TL cultural values, bringing the author back home, and foreignizing method, an ethnodeviant pressure on those values to register the linguistic and cultural differences of the foreign text, sending the reader abroad".(Venuti, 1995, p.20)

As luck would have it, Qian Zhongshu, a famous Chinese scholar, has a comment which appears to be a sheer reproductive version of Schleiermacher's: 钱氏认为，“化” 分为 “欧化” 和 “汉化”。 前者 “尽可能让外国作家安居不动, 而引导我国读者走向他们那里去” ; 而后者 “尽可能让 我国读者安居不动，而引导外国作家走向咱们这儿来”。（蔡新乐，2000，p.24）

In short, two orientation in cultural translation are domestication (or adaptation) and foreignization (or alienation). The former refers to target language culture-orientation, while the latter means source language culture-orientation.

\subsection{Main Techniques Adopted in the Translation of Simile and Metaphor.}

As we know, translation is not only a cross-linguistic activity but also a cross-cultural event. In translation, translators strive to convey not only the message of ST, but also its cultural connotations. However, due to their different social and cultural backgrounds, different languages have different choices of vehicles, which may hinder TL readers' understanding. In order to convey their cultural information and pragmatic meaning, translators have used different translation techniques.

\subsection{Literal Translation.}

Since people have some identical viewpoints in humanity, aesthetic standards beyond their time and space as a result of similar living environment and cognitive experience, people from different cultural backgrounds use some identical or similar similes and metaphors.

Example 1: 你就是你奶奶的总钥匙, 还要这钥匙做什么?

Yang's version: You're her master key. What does she want these keys for? (杨宪益, 2009, p.1018-1081)

In this example, Pinger is compared to a key, showing that she is very important to Wang xifeng. The translator adopts literal translation so as to reproduce the images of the SL culture. To target readers, this is an original metaphor at the first sight. On more reflection, they'll find the meaning of this metaphor, because "key" also means "important" in English.

Example 2: 上次我们跟了老太太进园逛去, 有一个水蛇腰、削肩膀、眉眼又有些象你林妹妹 的, 正在那里骂小个头。

Hawkes' version: Last time I was in the Garden with Lady Jia seeing a maid, a snaky-waisted girl with narrow, sloppy shoulders and something of your cousin Lin about the eyes, shouting at one of the junior maids. (Hawkes, 1980, p.834) 
Here, Lady Wang recalled the first time when she met Qingwen. She used such a vivid expression as “水蛇腰” to describe Qingwen. With a view to reproducing the SL culture, the translator uses the literal translation. As for target readers, they could easily figure out the similarities between snake and waist by their association.

\subsection{Literal Translation plus Explanation.}

Sometimes, a vehicle in SL has no corresponding vehicle in TL culture, or a vehicle in SL does have a corresponding vehicle in TL but the corresponding vehicle may convey a certain pragmatic meaning. On this occasion, translators may reproduce the same image with its relevant explanation added to the text. As a result, TL readers can visualize the fresh image in their culture with its cultural connotation explained.

Example 3: Every family is said to have at least one skeleton in the cupboard.

Version:俗话说，“衣柜里面藏骷髅”，见不得人的事家家有。（向玲, 2002, p.27-28) Example 4: 三个臭皮匠，合成一个诸葛亮。

Version: Three cobblers with their wits combined equal Zhuge Liang, the master mind.

In the above examples, images are well kept so as to preserve the exotic flavor of the source culture. In Example 3, “the skeleton in the cupboard” means family scandals. The explanation “见不 得人的事” helps the target readers taste the foreignness of another culture. In Example 4, Zhuge Liang is a famous counselor in the Chinese history. The explanation "the master mind" may satisfy the English readers' curiosity.

\subsection{Literal Translation plus Annotation.}

Though unfamiliar to target readers, some vehicles in ST play an important role in SL culture and style. In this case, translators strive to preserve those vehicles with relevant annotations added so that target readers can taste the exotic flavor.

Example 5: “难道这也是个痴Y头, 也像蘋儿来葬花不成? ” 因又暗自笑道: “若真是葬花, 可谓 ‘东施效蘋” 了，不但不为新奇，而且更为可厌。”

Yang's version: "Can this be another absurd maid who came to bury flowers like Daiyu?" He wondered in some amusement. "If so, she's Dong Shi imitating Xi Shi, which is not original but rather tiresome.”(杨宪益, 2009, p.848-849)

(Xi Shi was a famous beauty in the ancient kingdom of Yue. Dong Shi was an ugly girl who tried to imitate her ways.)

In this example, only when these historical backgrounds are stated clearly can target readers appreciate cultural connotations of simile and metaphor concerned.

\subsection{Substitution.}

In simile and metaphor, a vehicle often demonstrates its own national and cultural color. If a vehicle has no corresponding image in TL, we may reproduce it plus explanation or annotation. But if such a vehicle has its corresponding image in TL yet different association is aroused in the two cultures, we may replace it with another one in TL which conveys similar pragmatic meaning.

Example 6:小的扣紧，大的放松; 池子里捕鱼，太湖里放生。

Ying Yu's version: Fussy about trifles, careless about big things. Penny wise, pound foolish. (向玲, 2002, p.29)

In this example, Tai Lake is the third largest freshwater lake which has no corresponding word in English. So an ordinary reader would have no impression of how big it is. The replacement of the vehicle by another vehicle in English is really appropriate and wonderful. Although the image is changed, its pragmatic meaning remains the same.

\subsection{Free translation.}

Owing to the differences in culture, sometimes the vehicle in the SL is hard to keep and even though it can be kept, the translated text would be difficult for target readers to understand. In this case, translators often resort to free translation. Certainly such a strategy would more or less damage the expressiveness of metaphorical expressions. Therefore, translators should strive to make up for such a loss. 
Example 7: It's very plain that the old man I will remain at daggers drawn to the end of our lives, and that I have nothing to expect from him.

Version: 很明显, 我同老头子至死也势不两立, 我不会从他身上得到什么东西。（杜小惠, 2002, p.27)

Though not being the first choice, such a strategy would inevitably damage the esthetic function with the loss of the image, but at least its expressive effect can be kept with the conveyance of its pragmatic meaning.

\section{Conclusion}

As important figures of speech, simile and metaphor are deeply ingrained with traces of a particular society, reflecting unique cultural heritage. In terms of the translation of simile and metaphor, cultural elements are crucially important. One the whole, approaches to cultures involved in translation are divided into foreignization (SL culture-orientation) and domestication (TL culture-orientation). In order to reproduce cultural connotations and pragmatic meanings of simile and metaphor, translators often use these techniques: literal translation, literal translation plus explanation, literal translation plus annotation, substitution and free translation. Undoubtedly, new methods will be continuously invented for novel images so long as they serve to preserve cultural connotations and pragmatic meanings of the source language simile and metaphor.

\section{Acknowledgement}

This work is supported by Fundamental Research Funds for the Central Universities, Southwest University for Nationalities (No.2016SZYQN43).

\section{References}

[1]. Mary, Snell-Hornby. Translation Studies---An Integrated Approach. Shanghai Foreign Language Education Press, 2001, p.56.

[2]. Smith, Longan Pearsall. Words and Idioms. $5^{\text {th }}$.ed. Constable \& Company Ltd, 1943, p.10.

[3]. David, Katan. Translating Cultures: An Introduction for Translators, Interpreters and Mediators. St. Jerome Publishing, 1999, p. 2.

[4]. Lame, Hewson \& Jacky Martin. Refining Translation: The Variational Approach. World Publishing Corporation, 1993, p.25.

[5]. Susan, Bassnett, Translation Studies. Routledge, 1991, p.13.

[6]. Venuti, Lawrence. The Translator's Invisibility: A History of Translation. Routledge, 1995, p.19-20.

[7]. 蔡新乐.试论 “化境” 的反翻译倾向及 “不隔” 的理论意义，外语与翻译，2000，(1), p.22-29.

[8]. 杨宪益，戴乃迭. 红楼梦. 外文出版社，2009年，p.1080, p.848-849.

[8]. Hawkes, David. The Story of the Stone. Penguin Group, 1980, p.834.

[9]. 向玲.比喻翻译中的形象转换[D]. 华中师范大学, 2002, p.27-29.

[10].杜小惠.英汉比喻的文化差异及其翻译[D].华中师范大学，2002，p.27. 